(c) SW\&E, 2018

\title{
СПЕЦИФІКА СОЦАЛІЗАЦЇ̈ ЛЮДЕЙ ПОХИЛОГО ВІКУ В СУЧАСНОМУ СУСПІЛЬСТВІ
}

Yulia Lysenko,

Candidate of Pedagogical Sciences, Associate professor,

Professor of the Department of Social Work and Social Pedagogics Communal educational institution «Kharkiv

Humanitarian Pedagogical Academy» of Kharkiv Regional Council,

Kharkiv, Ukraine

yu25lysenko@gmail.com

ORCID: 0000-0003-3229-2880

\section{Юлія Лисенко,}

кандидат педагогічних наук, доиент,

професор кафедри соиіальної роботи та соиіальної педагогіки

Комунальний заклад «Харківська гуманітарно-педагогічна

академія» Харківської обласної ради

Харків, Україна

УДК 37.013.42 : [364.4-053.9 : $316.324 .8(045)$

DOI: $10.25128 / 2520-6230.18 .4 .3$

\section{Article history:}

Received: October 22, 2018

1st Revision: November 18, 2018

Accepted: December 30, 2018
АНОТАЦІЯ. На кожному віковому етапі розвитку особистості процес соціалізації зумовлений впливом соціокультурних чинників $і$ має свою специфіку. Люди похилого віку, які готуються до пенсї, завершення професійної діяльності, переживають своєрідну кризу, шьо безпосередньо діє на адаптаиію до нових умов життя. Знижені адаптаиійні можливості ускладнюють опанування нових викликів, пов'язаних $з$ умовами життедіяльності в інформаційному соціумі. Тому мета статті - виявити ключові особливості сочіалізачї осіб третього віку в сучасному суспільстві. Основні методи,використані в дослідженні, - аналіз, синтез, систематизація, узагальнення. Характерними особливостями соціалізації людей похилого віку нами визначено: успішність иього проиесу в залежності від способу життя в молодості; ставлення великих $і$ малих соиіальних груп, інститучій до иієї вікової категорії осіб; власного ставлення до себе, до оточуючих, до старіння; наявності адаптаційного ресурсу та можливостей самореалізачії людей похилого віку в умовах мінливості соиіуму. Проаналізовані «Стратегія державної політики 3 питань здорового та активного довголіття населення на період до 2022 року» та План заходів до неї підтвердили зачікавленість держави, актуальність та необхідність упровадження сочіально-педагогічної підтримки людей похилого віку в інформаційному суспільстві. Визначення особливостей сочіалізаиії иієї вікової групи дає підстави для розробки змісту сочіально-педагогічної підтримки, котра передбачає створення умов покращення даного прочесу з використанням мистецтва як засобу, щзо надає можливості для здійснення нереалізованих потреб, досягнення емоиійної стійкості, позбавлення негативних психічних станів, активізацію творчої діяльності, розширення кола сочіальних зв'язків у сучасних умовах тощо. Перспективою подальшого дослідження $\epsilon$ обтрунтування особливостей соиіально-педагогічної підтримки людей похилого віку в інформачійному суспільстві та доведення необхідності використання мистецтва для поліпшення їх процесу соиіалізації.

Ключові слова: специфіка; сойіалізація; люди похилого віку; інформачійне суспільство. 


\section{Вступ}

Соціалізація особистості залежить від багатьох факторів, а тому відрізняється на різних культурно-історичних етапах становлення суспільства. Кожній віковій стадії характерна відповідна специфіка соціального розвитку, що часто визначається умовами середовища життєдіяльності індивіда. Тому у філогенезі процес соціалізації особистості $€$ неоднорідним, а тим паче, ускладнюється, коли адаптаційний ресурс 3 віком об’єктивно зменшується, а інформаційний прогрес суспільства інтенсифікується. Актуальності та особливих рис набуває соціалізація людей похилого віку. Зважаючи на зміни, що відбуваються на фізичному, психічному, соціальному рівнях цієї вікової категорії, варто обов'язково підтримувати цей процес, створюючи сприятливі умови для захисту, збереження, активізації та урівноваження різноманітних процесів, ураховуючи як об'єктивні чинники впливу на соціалізацію, так і суб’ єктивні. Це зумовлює необхідність вивчення специфіки процесу соціалізації людей третього віку для організації вчасної й ефективної соціально-педагогічної підтримки та забезпечення умов якісного життя.

Соціалізацію геронтологічної групи вивчають наковці в галузі філософії, соціології, психології, соціальної геронтології, соціальної педагогіки і соціальної роботи. А. Мудрик, А. Рижанова досліджують основи процесу соціалізації, А. Аніщенко, Н. Ліфарєва, А. Мокряк - проблеми посттрудової соціалізації; Т. Коленіченко, О. Новікова - особливості соціальної адаптації людей похилого віку; В. Альперович, О. Коваленко О. Козлов, О. Краснова, Ж. Малахова - психологічні та соціально-психологічні аспекти подолання проблем осіб третього віку; М. Житинська, Г. Міннігалеєва - соціально-педагогічну роботу з людьми третього віку; Ю. Мацкевіч - підготовку фахівців-соціальних педагогів для роботи з людьми похилого віку; Д. Титов, О. Тополь, Є. Холостова - засади соціальної роботи з цією віковою категорією. Проблеми адаптації особистості в інформаційному соціумі розглядають Л. Тіхонова, В. Штанько; Б. Срасов, В. Шейко - культурологічні аспекти інформаційного суспільства в добу глобалізації; Г. та М. Берулави, О. Сергеєв, В. Тестов - розвиток особистості через освіту в інформаційному суспільстві; Д. Сршов, А. Малюк - інформаційну безпеку особистості. Бракує наукових розвідок, пов'язаних із виокремленням специфіки соціалізації літніх людей в сучасному суспільстві. Тому мета статті - виявити ключові особливості соціалізації осіб третього віку в сучасному соціумі. Для цього нами використані методи аналізу, синтезу, систематизації, що дають можливість детально вивчити стан розробленості зазначеної проблеми в науковій літературі, узагальнення опрацьованого матеріалу для визначення специфічних особливостей процесу соціалізації людей похилого віку в сучасних умовах.

\section{Основна частина}

Соціалізація особистості - складний і багатогранний процес, що здійснюється під впливом соціокультурних чинників, а тому є досить динамічним. Якщо в умовах традиційного соціуму існував культ мудрості, для якого характерним була повага до досвіду та знань людей похилого віку, що передавались наступним поколінням i сприяли позитивній соціалізації і перших, i других, то, починаючи з індустріального домінує культ молодості, оскільки здебільшого молодь $є$ генератором нових знань $\mathrm{i}$ розвитку інноваційних технологій. На наш погляд, заміна культу мудрості на культ молодості пов'язана 3 підвищенням вимог до конкурентоспроможності людини на 
ринку праці, що зумовлює необхідність опановувати нові знання, перманентно займатися самоосвітою, саморозвитком та самовдосконаленням при чому в різних напрямах, а не в одному, як це було раніше - професія на все життя. Підростаюче покоління вже готують до освіти протягом життя, а сучасні люди похилого віку свої дитинство та юність проживали в інших соціально-економічних і культурних умовах. Зважаючи на те, що сьогоднішні люди третього віку - вихідці 3 СРСР, коли пропагувалася чітка ідеологія, зрозумілі цінності, стабільність соціально-економічної сфери, в умовах сьогодення стикнулися з руйнуванням всього, що було звичним, та втратою впевненості в майбутньому. Хаос, відсутність необхідної соціальної мобільності в стрімко змінюваних умовах, відповідного цим викликам досвіду, нестача адаптаційного ресурсу поклали початок маргіналізації геронтологічної групи населення, соціальну ексклюзію, яку досі не вдається подолати через стереотипне сприйняття літніх людей як тих, які нічого корисного вже не в змозі зробити для громадськості, держави, країни.

У зв'язку $з$ технологізацією та інформатизацією українського суспільства інтенсифікуються всі процеси, що відображаються на життєдіяльності людей похилого віку, а тому вимагають швидкої адаптації до мінливості, особистої та соціальної активності, щоб не залишитися за «межами» побудови майбутнього. Оскільки в осіб третього віку адаптаційний потенціал поступово знижується, що уповільнює пристосування до швидкоплинних трансформацій, то в інформаційному соціумі вони частіше виступають об'єктами процесу соціалізації, ніж суб'єктами. Відтак необхідно сприяти прояву їх суб'єктності, активності, творчості, укріпленню міжпоколінних зв'язків та як наслідок - збереженню цілісності, самобутності національної культури.

Життя в період кардинальних змін є складним для будь-якої вікової групи, а тим паче для літніх людей, у яких вже сформована система цінностей, відпрацьовані моделі поведінки, набутий протягом попередніх років життя досвід. У давніх китайців існувало своєрідне прокляття: «Щоб ти жив у епоху змін», що свідчить про складність життя в часи суспільних перетворень. Тому людям похилого віку, насправді, важче за інші вікові категорії пристосовуватися до перманентних перемін, оскільки їхні життєві здобутки часто знецінюються і вважаються пережитками минулого, а їхній досвід не завжди є актуальним у зв'язку з інтенсивним науково-технічним поступом. На жаль, відсутність розуміння з боку зовнішніх інституцій на різних рівнях і необхідності подолання труднощів адаптації геронтологічної групи населення породжує формування негативного іміджу літніх людей, відповідного ставлення до них та неприйняття їх у суспільстві, що провокує появу стереотипів, котрі ще більше поглиблюють проблему соціалізації цих осіб. Беручи до уваги вище зазначене, варто визначити особливості самого процесу соціалізації людей третього віку в сучасних умовах для наповнення в подальшому змісту їх підтримки в інформаційному суспільстві.

Першою особливістю є те, що характер соијалізації людей у похилому віці залежить від способу життя в молодості. У різні історичні часи вчені підкреслювали необхідність підготовки підростаючого покоління до майбутнього старості, висуваючи ідеї виховання, що обов'язково вплинуть на останній період життя людини. Мислитель епохи Відродження П. Верджеріо, описуючи у своєму педагогічному трактаті «Про благородні нрави та вільні науки» виховання юнаків, 
постійно акцентував на необхідності всіляких досягнень у різних сферах, порівнюючи 3 тим, як це відображатиметься на старості: «I в старості можна бажати стати освіченим, але нелегко цього досягнути, якщо в ранній юності не озброїтися знанням за допомогою старання й праці. Отже, в юності треба підготувати для себе втіхи, що можуть тішити чесну старість. I ті заняття, що в юності тяжкі, у старості будуть солодким відпочинком. ... Якщо юнаків, якось не задовольнити в їхніх слабостях, властивих їх віку, то пороки їх віку підуть за ними до старості» («Образ человека в зеркале гуманизма ...», 1999, с. 106, 122). Схоже розуміння має Е. Роттердамський: «Воістину нічого ми так не пам'ятаємо в старості, як те, що ввібрали в юні роки» (Там само, с. 246). Цицерон у свій час зазначав, що занепад сил у старості зумовлений вадами молодості, а вправляння та стриманість сприяють збереженню ресурсу в старості (Цицерон, 1974, с. 14, 16). Підтвердження таким роздумам знаходимо й у значно пізніших наукових дослідженнях Е. Еріксона, О. Козлова, О. Якимової, які стверджують, що старість залежить від всього попереднього життя, тому i $\epsilon$ індивідуальною. Грунтовне дослідження філософського аспекту похилого віку в екзистенційному та соціокультурному вимірах здійснила О. Тополь. Вивчаючи філософію цього віку, науковиця дає розуміння цілісності життя людини, яке можливе лише за умови цінності та значимості кожного вікового періоду як унікального. 3 цим важко не погодитися, адже закладене в юні роки з віком не зникає, а укорінюється. Тому все набуте в період молодості відіграє важливу роль у пізньому віці, а тим паче в новому інформаційному просторі, що зумовлює специфічність підтримки соціалізації особистості третього віку на індивідуальному та суспільному рівнях.

Другою особливістю сочіалізації людей похилого віку є ставлення великих $i$ малих сочьальних груп, інституичій до ичісї вікової категорії осіб. У філогенезі яскраво виражена нестабільна динаміка ставлень до людей третього віку: від знищення їх 3 метою виживання інших членів общини до надання необмежених повноважень. Саме зовнішнє ставлення і впливає на характер соціалізації цієї вікової групи. Якщо раніше воно формувалося в процесі виховання молодших, то в умовах інформаційного суспільства ключовими є засоби масової інформації. Наприклад, Е. Роттердамський у педагогічному трактаті «Про виховання дітей» висловлює негативні характеристики старості у порівнянні з дитинством і молодістю, про що до нього важко знайти у філософів різних епох. Він, з одного боку, наводить приклад Сенеки, який говорив про те, що ніякий вік не є пізнім для навчання, з іншого - висловлює сумніви щодо цього, оскільки вважає, що є речі, які з віком не придатні для сприйняття. Наприклад, він порівнює пам'ять дітей і старих, що відображається на засвоюванні знань, зокрема при вивченні мов: «Те, що ми бачимо дітьми, так міцно вкорінюється в душі, немов ми бачили це вчора. А те, що сьогодні читаємо старими, якщо знову через два дня прочитаємо, здаватиметься нам новим» («Образ человека в зеркале гуманизма: мыслители и педагоги эпохи...», 1999, с. 269, 270-271). Далі він пише про те, що небажано, «щоб дітей для навчання основам грамотності віддавали під опіку дуже старим людям, майже похилого віку ... Я вважав за краще людину квітучого віку, від якої хлопчик не відвернеться $з$ огидою й який не соромитиметься приймати будь-яку личину» (Там само, с. 284). Акцентуючи увагу на цінності часу, яка є непоправною, автор закликає до необхідності робити все своєчасно, адже час швидкоплинний, молодість зайнята, а старість уже не здатна (Там само, с. 296). Л. Альберті у книзі «Про сім’ю» відзначав важливу виховну роль людей похилого віку та їх 
авторитетність у житті молоді. Він зазначав, що, по-перше, люди похилого віку можуть отримати, закріпити та зберегти свій авторитет і гідність лише, проявляючи турботу про молодь, спрямовуючи, тим самим, їх на шлях доброчесності. Також старі мають бути для всіх спільними батьками, розумом і душею всієї родини. Тих, хто не приділяє достатньо уваги домашнім і можуть допустити ганьбу сім’і, заслуговують на осуд (Там само, с. 143). Відтак старі мали бути гідним прикладом, який наслідували молоді, а обов'язок молодих полягав у тому, щоб любити, слухатися, поважати, шанувати старих. Він писав, що великий вік передбачає багатодосвідченість, знання різних звичаїв, типів поведінки, людських душ, той, хто досяг цього віку «чув, бачив та обміркував безкінечну безліч корисних речей, а також чудові засоби захисту від будь-яких зрадливостей фортуни» (Там само, с. 144). Філософ-гуманіст закликав молодих людей бути уважними та шанобливими до людей похилого віку, слухатися їх і цінувати. При цьому акцентував увагу на тому, що бездіяльність та недбальство старших породжує непослух та непокору дітей (Там само, с. 145, 165). Отже, на прикладах Л. Альберті можемо спостерігати взаємообумовленість ставлень похилих людей і молодих. На наш погляд, саме ставлення осіб третього віку до дітей, молоді (для яких вони є певний час прикладом) зумовлює відповідну зворотну віддачу. Так, проведене дослідження 20-річної давності показало наступні результати: ставлення похилих людей до молоді здебільшого негативне, зумовлене нерозумінням, стереотипами, претензіями, негативними характеристиками (недисциплінованість, низька працьовитість, егоїзм, нечесність, непорядність, нехтування думкою та досвідом старших тощо) («Психология старости и старения», 2003, с. 357-358). На наш погляд, це може бути однією 3 основних причин, але не єдиною, негативного ставлення молоді до літніх людей - «що посієш - те і пожнеш». Якщо існує неприйняття похилими людьми молодих, то відтворюється відповідне ставлення, що спричиняє руйнування міжпоколінних зв’язків, загострення конфліктів і відособлення субкультури молоді від людей третього віку. Наслідком стає прірва між поколіннями, що порушує спадкоємність культурних традицій, передачу соціокультурного досвіду. М. Греллер, у свою чергу, стверджує, що зміни у свідомості літніх людей зумовлюються діями саме їхнього оточення. Так у культурі формуються оціночні уявлення, якою має бути людини та іiі поведінка на різних вікових етапах свого розвитку, зокрема у похилому віці (Там само, 2003, с. 259), зароджуються й укорінюються негативні суспільні стереотипи стосовно старості та людей третього віку, проявляється зневага до них, нерідкими є прояви ейджизму та як наслідок маргіналізація та соціальна ексклюзія геронтологічної групи населення. Для зміни негативного іміджу людей похилого віку з боку суспільства, варто їм самим більше себе проявляти як активних, позитивних, оптимістичних, яких неможливо не поважати. 3 соціальної педагогіки знаємо, що це зумовлюється ставленням до себе.

Набутий досвід протягом прожитих років залежить від багатьох як об' єктивних, так і суб'єктивних чинників. Тому нами визначена третя особливість соціалізації людей похилого віку - власне ставлення до себе, до оточуючих, до старіння. Давньоримський філософ М. Цицерон (106-43 до н.е.) у трактаті «Про старість» визначив 4 причини жалюгідної старості та розкрив ступінь важливості, виправданості чи хибності кожної, які варто розглянути. 1) Старість перешкоджає діяльності. Цицерон доводить різними прикладами помилковість цієї причини, порівнюючи старість і молодість. Він зазначає, що саме через вправляння люди похилого віку 
здатні зберегти свій розум і пам'ять, адже все, що їх турбує, вони зазвичай пам'ятають. Людина молода вправляється силою м'язів, а людина у віці - мудрістю, авторитетом, рішеннями: «... найвеличніші держави руйнувалися 3 вини людей молодих i охоронялися та відновлювалися зусиллями старих ... Необачність, очевидно, властива квітучому віку, далекоглядність - похилому» (Цицерон, 1974, с. 12). Для мудрих старих приємним є спілкування із молодими, що полегшує їхню старість, якщо останні шанують їх, цінують їхні настанови, поради тощо (Там само). 2) Старість послаблює тіло. Цицерон закликає до того, що старості треба чинити опір, адже це не тіло слабшає до старості, а здоров'я таким і було - слабким, а підтримувати необхідно розум та дух. Людина, яка постійно чимось зайнята, не відчуває приходу старості, вона старіє поступово (Цицерон, 1974, с. 16-17). М. Пальмієрі, у свою чергу, писав, що у старих людей має бути більше вправ для душі, а заняття фізичною працею варто скорочувати. Однак засуджував таку бездіяльність, яка призводить тіло до в’ялості, хворості, немочі, адже досвідчені літні люди мають подавати гарний приклад i допомагати своєю мудрістю та порадами наскільки це можливо державі, молоді, друзям («Образ человека в зеркале гуманизма: мыслители и педагоги эпохи Возрождения о формировании личности (XVI - XVII вв.)», 1999, с. 195-196). 3) Старість позбавляє майже всіх насолод. Хибність полягає в тому, що у старості є чим насолоджуватися, наприклад, головуванням за столом, зустрічами та бесідами 3 сусідами, літньою прохолодою чи сонцем, вогнем, можна отримувати насолоду від дозвілля, занять наукою, землеробства тощо, а молодість забирає найбільш порочне. У цілому, людина, яка не потребує чогось, у неї не можна цього і відібрати (Цицерон, 1974, с. 13-14, 16-17, 19). Буркотливість, неспокій, роздратованість, скупість недоліки характеру, а не старість. 4) Старість наближує до смерті, а конкретної межі старості немає, тому люди живуть, виконують свої справи і зневажають старість (Там само, с. 24, 26). Мислитель акцентує на тому, що мудрість є найголовнішою для прийняття своєї старості, адже тим людям, які незадоволені власним життям, важко в будь-якому віці (Там само, с. 8). Відтак причина криється в характері людини, а не у іiі віці. Тож, якість життя у старості залежить, перш за все, від характеру особистості, ставлення до самої себе та оточуючих, а також прийняття власного віку й змін у способі життя, що безпосередньо впливає на ії соціалізацію. Л. Валла у роботі «Про істинне та хибне благо» виокремив 4 якості доброчесності для досягнення особистого блага: розсудливість - проявляється в умінні передбачати вигідне для себе та уникати несприятливе: «Марна мудрість того мудреця, який не може бути корисний самому собі» («Образ человека в зеркале гуманизма ...», 1999, с. 60); помірність - слід утримуватися від якоїсь однієї радості, щоб насолоджуватися багатьма іншими; справедливість - здобути прихильність людей до себе та отримати вигоду; скромність - здобути авторитет та прихильність людей тим, що немає безглуздості в жестах, одязі, ході, голосі, обличчі. Таким чином, автор пропонує жити так, щоб уміти радіти корисності інших людей та намагатися, щоб вони любили тебе, оскільки бути корисним іншому передбачає і користь собі (Там само, с. 60, 62). Отже, дійсно фізичне, психічне, соціальне самопочуття літньої людини не в останню чергу залежить від їі ставлення до себе, прийняття себе незалежно від віку, теж саме стосується оточуючих людей, ситуацій і явищ, зокрема старості. Існує думка, з якою ми погоджуємося, що «старі люди інколи стають ейджистами по відношенню до власної вікової групи» («Психология старости и старения», 2003, с. 362). Дійсно, часто 
люди сприймають собі подібних негативно: критикують, заздрять, зверхньо поводяться, намагаються створити собі імідж сучасної моложавої особи в порівнянні 3 такими ж однолітками. Це звичайно накладає відбиток на характер соціалізації конструктивний чи деструктивний та подальше життя особистості. Для людей похилого віку є важливою підтримка громадянської позиції. 3 віком вона може як підвищуватися, так і знижуватися. Ця сфера дає волю людині проявляти свою активність в соціокультурному, політичному, економічному прогресі держави. М. Пальмієрі у своєму діалозі «Про громадянське життя» висуває концепцію людини, яка має жити за ідеалами громадянськості. Він стверджує, що найбільша любов у житті людини - любов до батьківщини та до дітей. Це обумовлено тим, що будь-яке інше благо завершується разом із життям, а це залишається після смерті. Ті громадяни, які протягом життя захищали, оберігали, сприяли розквіту держави, після смерті мають місце на небі. «Ніяка людська діяльність не може бути кращою, ніж піклування про спасіння батьківщини, охорону міста та зберігання союзу і злагоди, з'єднаних на благо мас...» («Образ человека в зеркале гуманизма ...», 1999, с. 54-56). Поряд із цим, він підкреслює виховну роль людей похилого віку, говорячи про необхідність власним життям надавати приклад підростаючому поколінню, яке має шукати підтримку і схвалення старих (Там само, с. 193). Отже, позитивне ставлення осіб третього віку до себе та до інших, здатність приймати власну старість не як завершення життя, а вміння відкривати нові обрії для самореалізації, проявляти соціальну активність, налагоджувати конструктивне спілкування з оточуючими та інше, що дає контент для здійснення ефективної підтримки даної вікової групи в інформаційному суспільстві.

Усе це можливо за наявності адаптаціийного ресурсу та можливостей самореалізаиї людей похилого віку в умовах мінливості сочіуму, що є четвертою особливістю їх соціалізації. Значна кількість сучасних дослідників звертається до розгляду соціальної адаптації осіб третього віку в сучасних умовах: Т. Коленіченко, Ж. Малахова, А. Мокряк, О. Новікова, А. Рижанова, Л. Тіхонова, В. Штанько й ін. Так, А. Рижанова, спираючись на дослідження В. Фролькіса, акцентує увагу на тому, що варто керувати старінням, а це залежить від уміння пригнічувати поступовий процес зниження адаптації та стимулювати мобілізацію необхідних механізмів для успішного пристосування до нових умов (Рижанова, 2011). Ж. Малахова, у свою чергу, зауважує, що благополучна адаптація людини похилого віку залежить від іiі позитивного настрою, запланованих дій, розуміння подальших перспектив, а також підтримки родини і повсякденної творчої діяльності (Малахова, 2010, с. 74). Грунтовне вивчення соціальної адаптації людей похилого віку до умов інформаційного суспільства, здійснене О. Новіковою, доводить, що це «активний творчий процес оновлення їх соціального досвіду здобутками культури інформаційного суспільства для пристосування до нього» (Новікова, 2015, с. 9). В авторефераті Т. Коленіченко знаходимо лише фактори та механізми соціальної адаптації людей похилого віку до нового середовища, а чітко окреслених та обгрунтованих особливостей, на жаль, немає. Л. Тіхонова, В. Штанько розглядають чотири типи соціальної адаптації особистості в інформаційному суспільстві, що, на наш погляд, стосується і людей похилого віку: неуспішний, успішно-пасивний, успішно-активний і вірогідніснокомбінований. Для перших двох видів характерною є пасивність особистості або низька особистісна активність; для третього - висока активність, що є двигуном засвоєння нового (цінностей, норм, правил), властиві соціально спрямована активна 
поведінка, самостійність та відповідальність, комунікабельність та емоційна стійкість; для четвертого - особистість здатна оцінювати вимоги соціального середовища, власний потенціал, деструктивні впливи тощо («Проблеми адаптації особистості в умовах становлення інформаційного суспільства», 2013, с. 52-53). Отже, можемо підсумувати, що підтримка та підвищення адаптаційного ресурсу людей похилого віку може сприяти їх самореалізації в умовах інтенсивних змін соціуму. У трактаті «Про виховання дітей і про їх гідні звичаї» М. Веджо зазначає, що інтелект і розум неможливо ані знищити, ані зруйнувати, тому 3 плином часу все зменшується, а знання та розсудливість в старості примножується («Образ человека в зеркале гуманизма ...», 1999, с. 222). Для підвищення якості адаптації та підтримки соціалізації, на наш погляд, варто було б використовувати мистецтво, оскільки воно надає можливості для здійснення нереалізованих потреб, досягнення емоційної стійкості, позбавлення негативних психічних станів, активізацію творчої діяльності, розширення кола соціальних зв'язків у сучасних умовах.

Підтвердженням актуальності та необхідності здійснення соціальнопедагогічної підтримки людей похилого віку в умовах інформаційного соціуму стає схвалення Кабінетом Міністрів України «Стратегія державної політики 3 питань здорового та активного довголіття населення на період до 2022 року» (від 11 січня 2018 р. № 10-p) (далі - Стратегія), а також розпорядження «Про затвердження плану заходів з реалізації Стратегії державної політики з питань здорового та активного довголіття населення на період до 2022 року» (від 26 вересня 2018 р. № 688-р) (далі План заходів) . Проаналізувавши ці документи, можемо зробити наступні висновки. На основі зазначеного у Стратегії національного демографічного прогнозу щодо збільшення кількості осіб похилого віку стає зрозуміло, що громадянами похилого віку визнаються люди від 60 років і старше. Також у документі відзначено, що старіння населення впливає на різні сфери життя суспільства та призводить до зміни потреб у цих сферах, що зумовлює необхідність визначення комплексних заходів для підтримки людей похилого віку, захисту прав і підвищення якості життя. На наш погляд, Стратегія має досить потужний соціально-педагогічний аспект, оскільки суттєвий відсоток окреслених проблем (відсутність програм соціальної підтримки, недостатня поінформованість щодо можливої участі в таких програмах, щодо ведення здорового способу життя, недооцінка потенціалу осіб похилого віку, стереотипні уявлення про старіння та літніх людей, що призводить до дискримінації в різних сферах життя та інші) можуть бути розв'язані саме за допомогою соціальної педагогіки та відповідно й упровадження соціально-педагогічного підходу в реалізацію необхідних заходів. У Стратегії виділено чотири пріоритетні напрями, що передбачають консолідацію зусиль різних інституцій - органів виконавчої влади, місцевого самоврядування, громадськості та бізнесу. Перший - поліпшення умов для самореалізації громадян похилого віку та їх участі у процесах розвитку суспільства передбачає стимулювання продовження трудової діяльності, поліпшення умов праці, розширення можливостей для передачі професійного досвіду молодшим, сприяння волонтерству, спрямування політики на навчання протягом життя, зокрема інформаційним технологіям, сприяння ресоціалізації, зокрема внутрішньо переміщених осіб. Другий - збереження здоров’я та забезпечення добробуту громадян похилого віку - спрямований на підвищення мотивації до активного довголіття через фізичну активність, профілактику захворювань, своєчасну геріатричну допомогу, 
доступність послуг. Третій - створення середовища, сприятливого для активного життя громадян похилого віку - планується формування позитивного ставлення до літніх людей через популяризацію та інформаційно-просвітницьку діяльність, розвиток інноваційних соціальних послуг, забезпечення доступності до об'єктів соціальної інфраструктури в сільській місцевості, залучення волонтерського ресурсу до створення та роботи дозвіллєвих, навчальних центрів, організації груп само- та взаємодопомоги, розвиток соціальної відповідальності бізнесу із спрямованістю на громадян похилого віку, формування позитивного ставлення суспільства до цієї вікової категорії, зміцнення зв'язків між поколіннями, запобігання дискримінації. Четвертий - створення системи захисту прав - передбачає підвищення рівня правової освіти людей похилого віку, проведення профілактичних заходів, спрямованих на захист від дискримінації, домашнього насильства, жорстокого ставлення, а також запровадження механізмів збереження майна (Стратегія, 2018). На жаль, сформульовані у Стратегії очікувані результати, менш значущі, ніж передбачено іiі завданнями. Запропонований План заходів містить досить цікаві, грунтовні пропозиції, що дійсно сприятиме реалізації поставлених завдань при належному його виконанні. Нами було відзначено ті заходи, що можуть стосуватися саме соціальнопедагогічної підтримки людей похилого віку для їх успішної соціалізації. 3 нового, що планується запровадити: професійну орієнтацію громадян похилого віку, збільшити кількість волонтерів даної вікової категорії в державному/комунальному секторах, розробити законопроект про забезпечення державної соціальної підтримки, ввести години спілкування та позакласні заходи (1 раз на квартал) у закладах загальної середньої та професійно-технічної освіти, спільні вечори/зустрічі в молодіжних центрах, бібліотеках, запровадження програм, зокрема «Програма менторства», «Прийомні бабусі та дідусі», внесення змін до законодавства щодо особливостей навчання людей похилого віку, організацію короткострокових курсів комп'ютерної грамотності, іноземних мов, роботи сучасних електронних платіжних систем, консультативної підтримки, розвиток соціально-педагогічної послуги «Університет третього віку» в сільській місцевості, участь громадян похилого віку в олімпіадах, спартакіадах саме для цієї вікової групи, залучення до різних культурних заходів (благодійних вистав, концертів, мистецьких виставок), створення циклу теле- та радіопередач щодо здорового способу життя, введення нової професії «соціальний робітник 3 основами медичних знань», включення в освітньо-професійну програму підготовки/перепідготовки фахівців із соціальної роботи, соціальних працівників курс 3 організації геріатричної допомоги та паліативного догляду, питань, що пов'язані 3 домашнім насильством, жорстоким поводженням, створення відеоматеріалів, зокрема соціальної реклами, щодо взаємної відповідальності поколінь та формування позитивного ставлення до цієї вікової категорії осіб, участь людей третього віку у формуванні національної політики зі здорового та активного довголіття, сімейні форми догляду за літніми людьми, залучення соціально відповідального бізнесу для підтримки, утворення комісії із захисту прав та інтересів громадян похилого віку, впровадження соціальних послуг посередництва (медіації), представництва інтересів тощо. Звертається увага на гендерні аспекти з метою недопущення дискримінації (План заходів; Стратегія, 2018). На наш погляд, запропонований перелік заходів $\epsilon$ цікавим. На наш погляд, варто було б активніше використовувати мистецтво в 
різноманітних заходах, оскільки воно є доступним та ефективним для підтримки соціалізації людей похилого віку.

\section{Висновки}

Отже, проаналізовані нами дослідження дали підстави для виявлення особливостей соціалізації людей похилого віку: характер соціалізації людей у похилому віці залежить від способу життя в молодості; ставлення великих і малих соціальних груп, інституцій до цієї вікової категорії осіб; власного ставлення до себе, до оточуючих, до старості; наявності адаптаційного ресурсу та можливостей самореалізації людей похилого віку в умовах мінливості соціуму. Ці особливості $є$ основою для визначення специфіки та змісту соціально-педагогічної підтримки осіб третього віку в інформаційному суспільстві, що $є$ перспективами подальших досліджень.

\section{Література}

Коленіченко, Т. (2010). Особливості адаптації людей похилого віку до умов нового соціального середовища. Автореф. дис. ... канд. пед. наук: 13.00 .05 / Національний педагогічний університет імені М. П. Драгоманова. Київ, 25.

Малахова, Ж. (2010). Соціальна геронтологія: курс лекцій для студентів вищих навч. закл. Запоріжжя: КПУ, 180.

Новікова, О. (2015). Соціально-педагогічна адаптація людей похилого віку до умов інформаційного суспільства. Автореф. дис. ... канд. пед. наук: 13.00.05 / ДЗ «Луганський нац. ун-т імені Тараса Шевченка». Старобільськ, 20.

Образ человека в зеркале гуманизма: мыслители и педагоги эпохи Возрождения о формировании личности (XVI - XVII вв.) / Сост., вступ. статьи и коммент. Н.В. Ревякиной, О.Ф. Кудрявцева. Москва: Изд-воУРАО, 1999. 400.

Проблеми адаптації особистості в умовах становлення інформаційного суспільства: монографія / В.І. Штанько, Л.А. Тіхонова та ін. Харків: ООО «Компанія CMIT», 2013. 172.

Психология старости и старения: Хрестоматия: учеб. пос. для студентов психол. фак. высш. учеб. заведений / Сост. О.В. Краснова, А.Г. Лидерс. Москва: Издательский центр «Академия», 2003. 416.

Рижанова, А. (2011). Люди похилого віку в інформаційному суспільстві: соціально-педагогічний підхід. Педагогіка та психологія. Вип. 40(2), 128-137. URL: http://nbuv.gov.ua/UJRN/znpkhnpu ped $201140 \% 282 \% 29 \quad 23$ (дата звернення: 04.12.2018).

Про затвердження плану заходів 3 реалізації Стратегії державної політики 3 питань здорового та активного довголіття населення на період до 2022 року: розпорядження Кабінету Міністрів України від 26 вересня 2018 р. № 688-p. URL: http://zakon.rada.gov.ua/laws/show/688-2018-\%D1\%80 (дата звернення: 04.12.2018).

Про схвалення Стратегії державної політики 3 питань здорового та активного довголіття населення на період до 2022 року: розпорядження Кабінету Міністрів України від 11 січня 2018 р. № 10-p. URL: https://www.kmu.gov.ua/ua/npas/proshvalennya-strategiyi-derzhavnoyi-politiki-z-pitan-zdorovogo-ta-aktivnogo-dovgolittyanaselennya-na-period-do-2022-roku (дата звернення: 04.12.2018).

Цицерон, М. (1974). О старости. О дружбе. Об обязанностях / сост. В.О. Горенштейн, М.Е. Грабарь-Пассек, С.Л. Утченко. Москва: Наука, 249. 


\title{
SPECIFICATION OF SOCIALIZATION OF THE ELDERLY PEOPLE LIVING IN THE INFORMATION SOCIETY
}

Lysenko Yulia, Candidate of Pedagogical Sciences, assistant professor, Professor of the Department of Social Work and Social Pedagogics

Communal educational institution «Kharkiv Humanitarian Pedagogical Academy» of Kharkiv Regional Council yu25lysenko@gmail.com

\begin{abstract}
At each age stage of personality development, the process of socialization is due to the influence of socio-cultural factors and has its own specificity. The elderly people preparing to retire and complete their professional activities are experiencing a peculiar crisis that directly affects the adaptation to new living conditions. The reduced adaptive capacity makes it difficult to respond to new challenges associated with living conditions in the information society. Therefore, the purpose of the article is to identify the key features of the third age people socialization in the modern society to determine the content of their socio-pedagogical support. The main methods used in the given study are analysis, synthesis, systematization, and generalization. The determined characteristic features of the elderly people socialization are the following: the success of this process, depending on the way of life in youth; the attitude of large and small social groups and institutions to this age group of persons; the attitude towards oneself, to others, to aging; the availability of an adaptation resource and opportunities for self-realization of the elderly in conditions of the fluidity of society. The analyzed "Strategy of the state policy on the issues of healthy and active longevity of the population for the period up to 2022» as well as its Action plan confirmed the interest of the state, the urgency and necessity of introducing the social and pedagogical support of the elderly in the present day information society. The definition of the peculiarities of this age group socialization provides grounds for the development of the content of social and pedagogical support, which involves creating conditions for improving this process, using art as a means that provides opportunities for implementing unmet needs, achieving emotional stability, getting rid of negative psychic states, activating artistic endeavor, extension of the range of social ties under current circumstances, etc. The prospect of further research lies in substantiating the peculiarities of social and pedagogical support of the elderly people in the information society and to prove the necessity of using art to improve their socialization process.
\end{abstract}

Key words: specificity; socialization; elderly people; information society.

\section{Reference}

Kolenichenko, T. (2010). Adaptation peculiarities of the elderly people to the conditions of the new social environment. Extended abstract of Candidate thesis. Kyiv: National Pedagogical University named after M.Dragomanov [In Ukrainian].

Malakhova, Zh. Social gerontology: a course of lectures for students of higher educational institutions. Zaporizhia: KhPU, 2010, 180 p. [In Ukrainian]. 
Novikova O. (2015). Socio-pedagogical adaptation of the aged people to the information society. Extended abstract of Candidate thesis. Starobelsk: State Institution „Luhansk Taras Shevchenko National University”. [In Ukrainian].

On approval of the plan of measures for the implementation of the State Policy Strategy on healthy and active longevity of the population for the period up to 2022: the order of the Cabinet of Ministers of Ukraine dated September 26, 2018, No. 688-p. URL: http://zakon.rada.gov.ua/laws/show/688-2018-\%D1\%80 (application date: 04.12.2018). [In Ukrainian].

On Approval of the Strategy of the State Policy on Healthy and Active Longevity of the Population for the period up to 2022: the order of the Cabinet of Ministers of Ukraine dated January 11, 2018, No. 10-p. URL: https://www.kmu.gov.ua/ua/npas/pro-shvalennya-strategiyi-derzhavnoyi-politiki-zpitan-zdorovogo-ta-aktivnogo-dovgolittya-naselennya-na-period-do-2022- roku (application date: 04.12.2018). [In Ukrainian].

Problems of personality adaptation in conditions of the information society formation: monograph / V. I. Shtanko, L.A. Tikhonova, etc., Kharkiv: «Company SMIT LLC», 2013, 172 p. [In Ukrainian].

Psychology of old age people and aging: Chrestomathy: study guide for students of psychology departments of higher educational institutions / Authors: O.V. Krasnova, A. G. Liders, Moscow: Publishing Center «Akademiya», 2003, 416 p. (rus)

Ryzhanova, A. Older people in the information society: socio-pedagogical approach. Pedagogy and Psychology. 2011. Issiue 40 (2). Pp. 128-137. URL: http://nbuv.gov.ua/UJRN/znpkhnpu_ped_2011_40\%282\%29_23 (application date: 04.12.2018). [In Ukrainian].

The image of man in the mirror of humanism: thinkers and educators of the Renaissance about the development of the individual (XVI - XVII cen.) / Cont., introduction to the article and comments. N.V. Reviakina, O.F. Kudriavtseva Moscow: Publishing House URAO, 1999, 400 p. [In Russian].

Tzitzeron, M. To the problem of old age. To the problem of friendship. To the problem of duties / Authors: V. O. Gorenshtein, M. E. Hrabar-Passek, S. L. Utchenko, Moscow: Nauka, 1974, 249 p. [In Russian]. 
